\title{
MODEL BISNIS KANVAS DOC AYAM KAMPUNG PT PQR
}

\author{
BUSINESS MODEL CANVAS OF NATIVE CHICKEN DOC PT PQR
}

\author{
Aomi Hazelia Dewi ${ }^{*}$, Sukardi**), dan Fahim M. Taqi $\left.{ }^{* * *}\right)$ \\ *) Sekolah Bisnis, IPB University \\ Jl. Pajajaran Bogor 16151 \\ ${ }^{* *}$ Departemen Teknologi Industri Pertanian, Fakultas Teknologi Pertanian, IPB University \\ Gedung Fateta Lantai 2, Kampus IPB Dramaga, Bogor 16680 \\ ${ }^{* * *}$ Departemen Ilmu dan Teknologi Pangan, Fakultas Teknologi Pertanian, IPB University \\ Gedung Fateta Lantai 2, Kampus IPB Dramaga, Bogor 16680
}

\begin{abstract}
The poverty reduction program by the Indonesian government in 2018-2019 had appointed PT. PQR as the distributor of native chicken DOC. This study aimed to analyze the current PT PQR business model and improve the business model. The study used the Business Model Canvas. The findings were the followings. The Customer segment was classified as a niche market with Government as the largest consumer, and the rest was native chicken farmers. The value proportion was to offer vaccinated DOC of native chicken form pure local strain that meets the consumers' demand. Even though the most effective promotion and sales media was Facebook, PT PQR was unable to increase customer loyalty. The company income resources were sales of DOC, live birds, and fresh-cut native chicken. The main resources were machine, building facilities, and intellectual resources such as ISO management system, cooperation with some experts of BALITNAK and BPATP, and expert staff. The partnership was performed by the acquisition of resources and key activities. Key activities were production activity which relates to transportation from cages-egg reception, egg selection-fumigation-storage in cooling room-hatch-transfercandling-pull chick. The highest production costs of native chicken DOC were feed and vaccine costs. The improvement programs were increasing production capacity, increasing the number of employees, and cooperating with other native chicken companies.
\end{abstract}

Keywords: business model, business model canvas, business strategic, native chicken, production

Abstrak: Program pemerintah Indonesia tahun 2018-2019 mengenai pembagian DOC ayam kampung dalam rangka penanggulangan kemiskinan, PT PQR ditunjuk sebagai supplier DOC ayam kampung. Penelitian ini bertujuan menganalisis model bisnis PT PQR saat ini dengan bisnis kanvas model serta alternatif perbaikan model bisnisnya Metode penelitian dengan menggunakan Model Bisnis Kanvas. Segmen pelanggan termasuk pasar ceruk, yaitu Pemerintah yang merupakan pelanggan terbesar, sedangkan pelanggan lainnya ialah peternak ayam kampung. Proporsi nilai berupa penawaran galur murni ayam kampung kampung kualitas DOC sesuai keinginan pelanggan, dan DOC sudah divaksin. Saluran terefektif untuk sarana promosi dan penjualan ialah facebook, walaupun demikian PT PQR kurang dapat meningkatkan kesetiaan pelanggan. Sumber pendapatan perusahaan berasal dari penjualan DOC ayam kampung, ayam kampung hidup, dan ayam kampung potong. Sumber daya utama yang dikuasai berupa fasilitas bangunan dan mesin, dan sumber daya intelektual berupa sistem manajemen ISO, kerja sama dengan Balai Penelitian Ternak, dan staf ahli. Kemitraan dilakukan untuk mengakuisisi sumber daya dan aktivitas tertentu. Aktivitas kunci merupakan aktivitas produksi yang terkait dengan transportasi dari kandang-Penerimaan telur-Penyeleksian telur-Fumigasi-Penyimpanan di cooling roomPengeraman-Transfer-Candling-Pull chick. Biaya yang paling tinggi untuk memproduksi DOC ayam kampung ialah biaya pakan dan biaya vaksin. Program perbaikan berupa penambahan kapasitas produksi, penambahan jumlah karyawan, dan menjalin kerjasama dengan perusahaan ayam kampung lainnya.

Kata kunci: ayam kampung, bisnis kanvas model, model bisnis, strategi bisnis, produksi

\footnotetext{
${ }^{1}$ Alamat Korespondensi:

Email: aomihazeliadewi@gmail.com
} 


\section{PENDAHULUAN}

Pola konsumsi pangan masyarakat Indonesia masih didominasi oleh konsumsi kelompok pangan sumber karbohidrat dan masih kurangnya konsumsi pangan sumber protein. Ayam kampung salah satu sumber protein yang merupakan komoditas peternakan yang memiliki prospek yang baik. Perkembangan produksi ayam kampung juga terus meningkat dari tahun ke tahun. Kenaikan pada tahun 2017 sebesar 0,05\% dan pada tahun 2018 sebesar $0,04 \%$. Rata-rata produksi selama 5 tahun sebanyak 299,27 ribu ton per tahun. Rata-rata pertumbuhan produksi sebesar 0,01\% (Dirjen PKH, 2018). Di samping adanya peningkatan produksi, ayam kampung ini masih terkendala dalam pemenuhan permintaannya dikarenakan rendahnya produktivitas (Muryanto et al. 2009), sistem budidaya masih tradisional, dan berpeluang menyebarkan penyakit (Hudang, 2016).

PT PQR salah satu mitra perusahaan pembibitan ayam kampung. Sejak awal 2017 sudah melaksanakan perbanyakan dan penjualan DOC (day old chick) berupa final stock. DOC ayam kampung hingga saat ini belum dapat dipenuhi oleh PT PQR. Hal ini disebabkan oleh keterbatasan fasilitas produksinya yang belum memadai seperti jumlah mesin pengeram dan mesin penetas. Selain itu, saat ini pelanggan utamanya yaitu pemerintah dengan permintaan DOC ayam kampung sebanyak 4 juta DOC pada tahun 2018. Hampir semua DOC ayam kampung dipesan program pemerintah yang mendistribusikan DOC ayam kampung ke rumah tangga miskin. Program bedah kemiskinan rakyat sejahtera (BEKERJA) pemerintah berlangsung dari tahun 20182019. PT PQR meningkatkan kapasitas produksinya untuk memenuhi permintaan pemerintah tersebut. PT PQR harus menyusun strategi yang sebaiknya dilakukan untuk menyeimbangkan antara penambahan kapasitas produksi dan target pelanggannya setelah program pemerintah selesai. Menurut Kurniawan et al. (2013) untuk penambahan kapasitas harus diimbangi dengan peningkatan pangsa pasar dan adanya permodalan untuk meningkatkan kemampuan dalam membuat strategi pengembangan.

Berdasarkan permasalahan yang ada maka perlu dilakukan penelitian untuk mendapatkan solusi tersebut. Perusahaan membutuhkan model bisnis yang tepat untuk menemukan faktor-faktor apa saja yang menghambat dan mengembangkan PT PQR dengan menggunakan bisnis kanvas model. Dengan adanya pemetaan Model Bisnis Kanvas diharapkan mengetahui strategi apa yang sebaiknya dilakukan oleh perusahaan. Menurut Zott et al. (2011), model bisnis sangat membantu perusahaan untuk mengidentifikasi teknik baru sehingga menghasilkan nilai bagi pelanggan maupun perusahaan itu sendiri. Model Bisnis Kanvas yang baik dapat memberikan gambaran terkait respon pasar terhadap produk yang dihasilkan. Selain itu, dalam Model Bisnis Kanvas akan terlihat kinerja pelaksanaan perusahaan secara menyeluruh, sehingga dapat memudahkan pengambil keputusan dalam mengatasi persoalan komponen bisnis yang kurang optimal dalam hubungannya dengan komponen-komponen bisnis yang lainnya agar perusahaan mempunyai bisnis yang berkelanjutan. Penelitian ini bertujuan memetakan model bisnis yang dijalankan PT PQR saat ini.

Penelitian ini dibatasi pada bisnis model kanvas yang PT PQR berdasarkan hasil wawancara mendalam (depth interview) dengan pemilik, General manager, manajer produksi, manajer Human Resources and Development (HRD) \& General Affair (GA), manajer keuangan dan manajer pemasaran dari pihak PT PQR dan pakar peneliti dari Balai Penelitian Ternak (BALITNAK) Ciawi dan observasi lapang.

\section{METODE PENELITIAN}

Lokasi penelitian di wilayah Kecamatan Parung Kabupaten Bogor. Lokasi penelitian dipilih secara sengaja dengan pertimbangan bahwa PT PQR merupakan salah satu perusahaan ayam kampung unggul yang menjadi tempat perbanyakan DOC bibit ayam kampung untuk dikomersialisasikan. Kegiatan pengumpulan data dilaksanakan pada SeptemberDesember 2018.

Jenis data yang digunakan dalam penelitian ini adalah data primer dan data sekunder. Data primer berupa data produksi, penjualan, finansial, dan data sembilan elemen model bisnis kanvas. Data sekunder diperoleh dari studi literatur, jurnal, laporan hasil verifikasi kerjasama lisensi BALITBANGTAN, buku-buku, internet serta data dari instansi terkait seperti Badan Pusat Statistik, Kementerian Pertanian, dan Balai penelitian. Bentuk data yang digunakan dalam menganalisis model bisnis PT PQR saat ini adalah data kualitatif. 
Pengambilan data dalam penelitian ini dilakukan dengan beberapa metode, metode pertama yaitu metode wawancara (in depth interview) dilakukan dengan wawancara langsung dengan pihak internal manajerial perusahaan PT PQR dengan responden wawancara antara lain: Wakil Direktur, Direktur produksi, Breeding Farm Manajer, Manajer Keuangan, Manajer Human Resource/General Affairs, Manajer Purchasing, Sales DOC, dan Sales ayam hidup. Metode yang kedua, yaitu Kegiatan observasi dan survei dengan meninjau dan mengumpulkan informasi dari aktivitas dan proses bisnis PT PQR mulai produksi, pengelolaan, kegiatan penjualan sampai dengan ke konsumen.

Metode analisis data pada penelitian ini melalui dua tahapan yaitu dengan menggunakan analisis deskriptif kualitatif untuk mendapatkan gambaran umum PT PQR secara menyeluruh dan membuat desain Bisnis Model Kanvas dengan berdasarkan langkah berikut: Identifikasi sembilan elemen BMK, didasarkan atas kondisibisnis yang sebenarnya terjadi. Dalam tahapawal dari mendesain BMK, dimulai dari mengidentifikasi customer segments. Langkah selanjutnya adalahmengisi value propositions. Setelah itu Channels menjelaskan bagaimana mengkomunikasikan, mengantar, dan berinteraksi dengan pelanggannya. Perlu diperhatikan bahwa kesuksesan dalam kegiatan channels sangat ditentukan oleh efektifitas dari key resources, key activities, dan key partnership. Customer Relationships adalah seberapa besar aktivitas perusahaan menjaga hubungan dengan pelanggan lama. Apabila customer segments dapat difokuskan dengan baik, value propositions dinyatakan secara tajam serta channels dan Customer Relationships dijaga dengan benar, maka revenue stream akan terpenuhi. Kegiatan seperti key resources, key activities, dan key partnership harus dimanajemen secara baik dan efisien. Efiseinsi dalam pengelolaan tiga elemen terakhir sangat diperlukan untuk menjaga revenue stream dan cost structure tetap optimal.

Indentifikasi elemen model bisnis kanvas yaitu Customer segments melayani satu atau beberapa pelanggan, value propositions merupakan hasil dari pemecahan masalah dan kebutuhan pelanggan yang dapat dipenuhi perusahaan. Channel dilihat dari saluran komunikasi, penjualan, pemasaran dan distribusi yang digunakan. Customer relationships bagaimana hubungan perusahaan dengan pelanggan mengenai produk yang dijual. Revenue stream melihat apa saja yang menjadi sumber pendapatan perusahaan. Key resources dan key partnerships apa saja yang digunakan untuk menunjang key activities agar dapat berjalan dengan cost structure yang ada Hal yang perlu disadari dalam mendesain B.MK adalah menjaga keterkaitan antar elemen, karena perubahan pada satu elemen akan berdampak pada elemen lainnya. Alur ringkasan kerangka penelitian dapat dilihat pada Gambar 2.

\section{HASIL}

Analisis model bisnis PT PQR dilakukan dengan menggunakan analisis sembilan elemen pada Model Bisnis Kanvas berdasarkan teori Osterwalder dan Pigneur (2015). Elemen-elemen tersebut dianalisis secara berurutan agar tercipta integrasi yang tepat antara setiap elemen. Menurut Ching dan Fauvel (2013) Model Bisnis Kanvas pada awalnya harus digunakan oleh pengusaha ketika mereka semakin berpengalaman dengan penggunaannya. Model Bisnis dianggap menjadi sebuah pendekatan yang dapat mewakili nilai yang diciptakan oleh perusahaan dalam menyesuaikan strategi bisnis atau memasuki pasar baru (Shafer et al. 2005). Model Bisnis Kanvas PT PQR dapat dilihat pada Gambar 3.

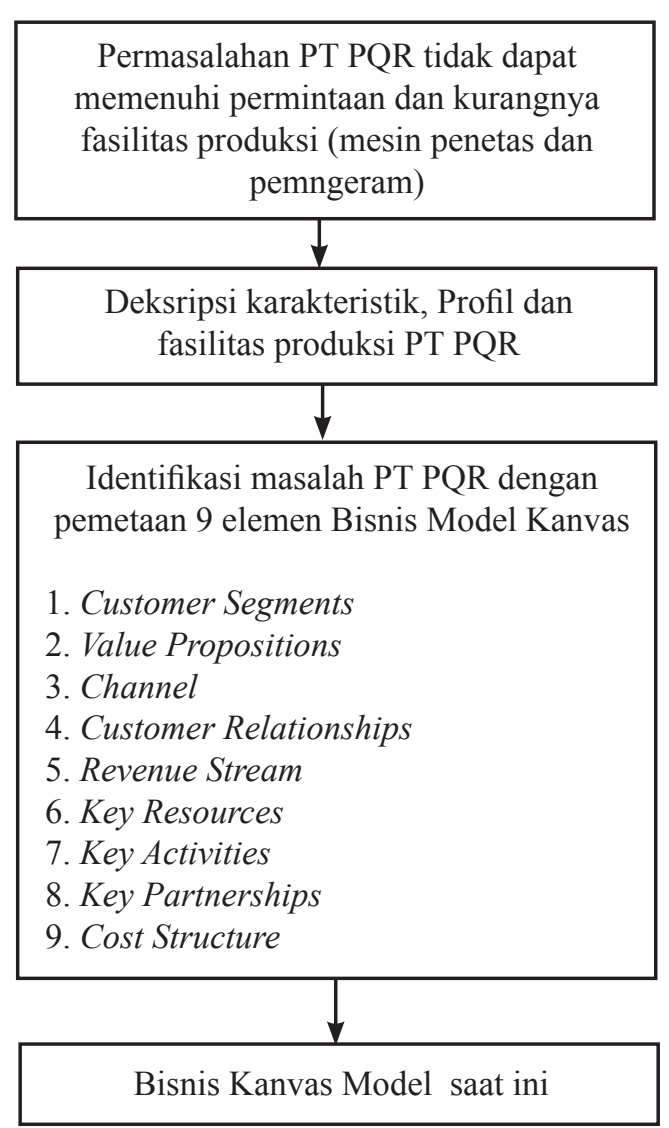

Gambar 2. Kerangka pemikiran penelitian 


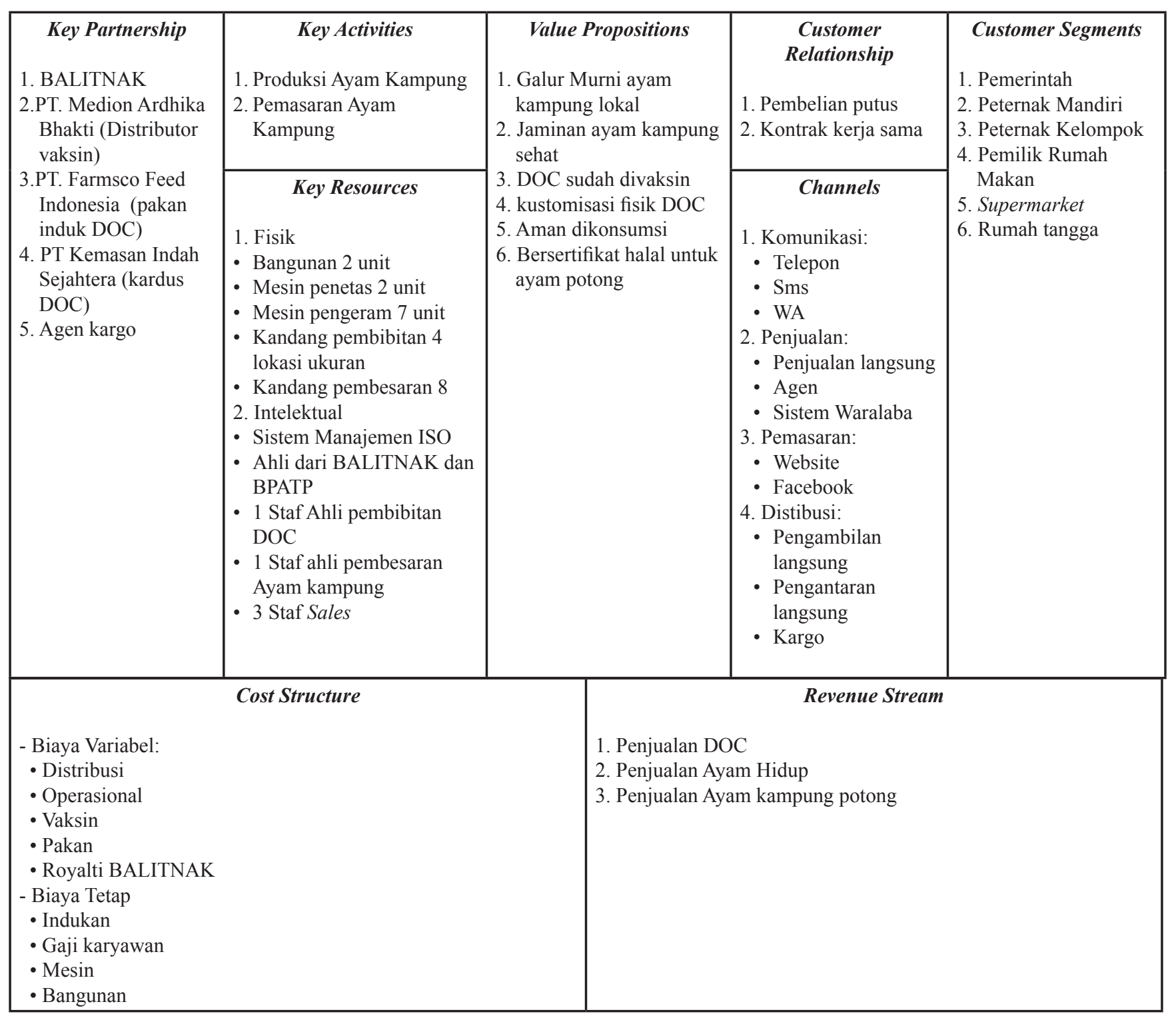

\section{Gambar 3. Model Bisnis Kanvas PT PQR}

\section{Segmen Pelanggan}

Pada elemen ini menggambarkan sekelompok individu maupun organisasi yang ingin dilayani oleh perusahaan. Pelanggan merupakan inti dari pembentukan model bisnis. Hal ini karena model bisnis sengaja dibentuk untuk dapat menjangkau pelanggan tertentu untuk membeli produk yang dihasikan perusahaan. Dalam pelaksanaan bisnis PT PQR segmen pelanggan yang dilayani termasuk jenis pasar ceruk. Segmen pelanggan pasar dari PT PQR termasuk pasar ceruk karena melayani pelanggan yang spesifik dan terspesialisasi. Pelanggan terbesar saat ini adalah Pemerintah. PT PQR ditunjuk sebagai penyuplai DOC ayam kampung dan ayam hidup untuk membantu program pemerintah pemerintah Bedah Kemiskinan Rakyat Sejahtera (BEKERJA). Pelanggan lainnya untuk DOC adalah Peternak ayam kampung. Peternak ayam kampung disegmenkan menjadi dua yaitu peternak mandiri dan kelompok peternak. Pengertian dari peternak mandiri, yaitu peternak yang mampu membeli DOC ayam kampung sendiri, sedangkan kelompok peternak yaitu gabungan dari peternak-peternak kecil yang bekerjasama untuk membeli DOC ayam kampung ke PT PQR untuk meminimalisir harga DOC dan biaya pengiriman apabila berada di satu daerah yang sama. Menurut Sari, Hudoyo, dan Nugraha (2015), pelanggan akan tetap membeli produk berulang dikarenakan adanya ketersediaan produk dan harga yang sesuai dengan kualitasnya. Segmen pelanggan yang dilayani untuk produk ayam hidup kampung adalah pemilik rumah makan ayam kampung yang berada di Jakarta, Tangerang, dan puncak. Sedangkan segmen pelanggan untuk ayam kampung potong, yaitu supermarket dan rumah tangga. 
Proposisi Nilai

Proposisi nilai merupakan elemen yang menggambarkan gabungan antara produk dan layanan yang menciptakan nilai untuk pelanggan spesifik. Menurut Dudin et al. 2015, Nilai adalah kemampuan perusahaan untuk memecahkan masalah konsumen dengan menawarkan produk (barang) tertentu. Nilai yang ditawarkan oleh PT PQR untuk pelanggannya dengan menawarkan galur murni ayam kampung lokal yang merupakan hasil dari persilangan grand parent ayam KUB dan ayam sensi. Selain itu, PT PQR sudah dilengkapi hak paten galur murni ayam kampung lokal dan surat keterangan kesehatan hewan. Hak paten galur murni ayam kampung lokal dan surat keterangan kesehatan hewan digunakan untuk meyakinkan ke pelanggan bahwa ayam kampung yang dijual asli Indonesia dan dipastikan aman untuk dijual. DOC ayam kampung yang banyak diminati konsumen mempunyai ciri-ciri dapat dilihat pada Tabel 1.

Tabel 1. Grade 1 DOC PT PQR

\begin{tabular}{ll}
\hline Spesifikasi & Parameter \\
\hline Bobot & Min 26 gram \\
Umur Induk & Min 25 Minggu \\
Fisik & Lincah, tidak cacat, dubur kering \\
Bulu & Kering dan Mengembang \\
Mata & Normal \\
Paruh & Normal \\
Kaki & Normal \\
\hline
\end{tabular}

Kualitas yang diinginkan pelanggan dapat disesuaikan dengan keinginan pelanggan, seperti pemilihan warna bulu, bobot fisik, mata, paruh, kaki DOC ayam kampung. PT PQR mampu melayani keinginan pelanggan seperti itu sehingga menjadi nilai lebih bagi PT PQR untuk menarik pelanggannya. Selain itu value propositions lainnya, yaitu DOC ayam kampung PT PQR sudah divaksin sehingga pelanggan tidak perlu memberikan vaksin kembali. value proposition untuk ayam kampung potong, yaitu aman dikonsumsi dan sudah bersertifikat halal.

\section{Saluran}

Pada elemen saluran ini menjelaskan mengenai bagaimana perusahaan menyampaikan produk kepada pelanggannya. Saluran yang terdapat di PT $\mathrm{PQR}$, yaitu saluran komunikasi, saluran penjualan, saluran pemasaran dan distribusi. Saluran komunikasi yang digunakan melalui telepon, sms dan whatsapp.
Pelanggan dapat menghubungi langsung Sales produk yang diinginkan. Sales produk dibagi menjadi tiga sesuai dengan produk yang disediakan PT PQR, yaitu Sales DOC, Sales ayam hidup dan Sales ayam kampung potong.

Saluran penjualan PT PQR melalui penjualan langsung, agen dan sistem waralaba. Penjualan langsung yang dilakukan PT PQR dimana Sales tiap produk dapat langsung dihubungi oleh pelanggan. Penjualan melalui agen hanya untuk produk ayam hidup. Agen membeli ayam hidup langsung ke PT PQR dan menyalurkan ke pelanggan rumah makan. Penjualan menggunakan sistem waralaba untuk produk ayam kampung potong. Sistem waralaba ini dilakukan dengan cara membuka kerjasama dengan siapa saja yang ingin menjadi partner kerja dengan modal lima juta rupiah dengan mendapatkan satu freezer dan 40 ayam kampung potong.

Website dan facebook adalah saluran pemasaran yang digunakan. Media sosial yang paling efektif selama ini yaitu melalui facebook. Media sosial tidak hanya untuk berkomunikasi dengan pelanggan saja tetapi dapat digunakan untuk berkomunikasi dengan supplier dan mitra juga (Barnes dan Jarcobsen, 2013). Pelanggan dapat mengetahui informasi terkini melalui facebook. Beberapa pelanggan ada yang langsung memesan produk ayam kampung melalui facebook. Saluran pemasaran melalui media sosial yang relatif murah dan gratis dapat membantu perusahaan untuk memulai menggunakan media sosial (Brooks et al. 2014).

Proses distribusi dilakukan dengan pengantaran oleh karyawan PT PQR atau dapat diambil langsung oleh peternak untuk wilayah JABODETABEK, sedangkan untuk di luar JABODETABEK menggunakan kargo barang antar sebagai pihak ketiga antara perusahaan dengan pelanggan. Biaya kargo ditanggung oleh pelanggan. Saluran ini bertugas mempertemukan pihak perusahaan dan pelanggan. Menurut Prabuwisudawan (2018), diperlukan adanya hubungan yang baik dengan seluruh mitra agar saluran distiribusi, baik informasi maupun komunikasi dapat berkembang sehingga nilai yang ditawarkan organisasi dapat tersampaikan secara merata ke seluruh pihak yang terkait dengan pengembangan peternakan di Indonesia. Media sosial yang paling efektif selama ini, yaitu melalui facebook. Pelanggan dapat mengetahui informasi terkini melalui facebook. Beberapa pelanggan ada yang langsung memesan DOC ayam kampung melalui facebook. 


\section{Hubungan Pelanggan}

Elemen hubungan pelanggan pada bisnis model kanvas merupakan jenis hubungan yang dibangun perusahaan bersama segemen pelanggannya (Osterwalder dan Pigneur, 2015). Hubungan pelanggan yang terjalin pada PT PQR yaitu hubungan yang hanya bertujuan menjual dan membeli produk antar Sales dan pelanggan. Menurut Bell et al. (2005), pelanggan profesional akan selalu proaktif dalam menjalin hubungan dengan perusahaan langganannya agar tidak mengeluarkan biaya untuk berpindah. Mereka akan berusaha untuk mempengaruhi kualitas layanan teknis yang disediakan perusahaan. Hubungan pelanggan yang terjalin, yaitu pembelian putus dan kontrak kerjasama. Pelanggan pemerintah melakukan pembelian dengan kontrak kerjasama sedangkan untuk peternak kelompok, peternak mandiri melakukan pembelian dengan pembelian putus. Tingkat kepuasan pelanggan dapat meningkatkan kinerja perusahaan dan keunggulan kompetitif Nashwan dan Hassan (2017).

\section{Arus Pendapatan}

Sumber pendapatan perusahaan berasal dari penjualan produk berupa DOC ayam kampung, penjualan ayam kampung hidup dan penjualan ayam kampung potong. Perusahaan berusaha memanfaatkan semua saluran untuk dapat memberikan keuntungan yang lebih besar. Memanfaatkan alur dari hulu ke hilir yang dapat dimanfaatkan menjadi produk yang dapat dijual. Ayam kampung potong dan ayam kampung hidup berasal dari DOC ayam kampung yang tidak memenuhi standar grade 1 lalu dibesarkan dan dipotong yang nantinya dijual ke pelanggan. Dalam arus pendapatan perusahaan yang sering terjadi adalah jenis arus pendapatan berulang. Hal ini karena beberapa pelanggan perusahaan melakukan pembelian secara berulang kepada perusahaan. Walaupun ada pula beberapa pelanggan yang hanya melakukan satu kali pembelian saja. Menurut Dewi (2018) loyalitas pelanggan memiliki peranan penting dalam sebuah perusahaan. Mempertahankan pelanggan berarti meningkatkan kinerja keuangan dan kelangsungan hidup perusahaan. Sumber modal PT PQR berasal dari pinjaman bank. Untuk meningkatkan kapasitas produksi yang berasal dari permintaan program pemerintah. PT PQR mendapatkan pinjaman dari bank untuk membantu membeli fasilitas produksi berupa mesin penetas dan penambahan jumlah karyawan.
Sumber Daya Utama

Pada PT PQR sumber daya utamanya termasuk kategori fisik, yaitu meliputi fasilitas bangunan dan mesin. Bangunan, mesin dan kandang dianggap sangat penting dalam pelaksanaan produksi. Apabila mesin maupun fasilitas bangunan bermasalah maka akan sangat mengahambat jalannya produksi sehingga akan memengaruhi kuota DOC ayam kampung dari pesanan pelanggan. Bangunan tempat produksi di PT PQR sudah sesuai dengan GMP (Good Manufacturing Practices). Mesin pengeram yang dimiliki PT PQR terdapat 2 jenis, yaitu mesin single dan multi. Mesin single mempunyi kapasitas 40.000 butir telur sedangkan multi mempunyai kapasitas 90.000 butir telur. Untuk kandang sendiri diperlukan untuk membesarkan ayam kampung hidup untuk dijual.

Sumber daya utama lainnya yaitu berupa sumber daya intelektual. Menurut Agustina (2015) sumber daya intelektual adalah segala sesuatu yang memiliki sifat kebendaan dan dapat dimiliki. Sumber daya intelektual yang dimiliki PT PQR adalah sistem manajemen yang dilaksanakan sudah terstandarisasi manajemen ISO. Menurut Abdelqader et al. (2007) sangat penting untuk peternak menerapkan manajemen yang baik untuk memproduksi ayam kampung. Sumber daya intelektual lainnya yaitu terdapat tenaga ahli dari BALITNAK untuk membantu teknologi peternakan, ahli dari BPATP untuk membantu promosi produk PT PQR. PT PQR pun memiliki staf ahli di bidang pembibitan yang mengerjakan proses produksi untuk menghasilkan DOC ayam kampung yang berkualitas, serta staf ahli pembesaran ayam kampung agar produk dapat dijual, dan staf ahli marketing untuk membantu memasarkan produk perusahaan. Staf ahli pembibitan, staf ahli pembesaran dan staf ahli marketing di setiap bagiannya hanya berjumlah satu orang. Menurut Zalkuwi et al. (2015), mempunyai staf ahli dapat mempengaruhi produktivitas perusahaan.

\section{Aktivitas Kunci}

Seperti yang telah dijelaskan pada elemen sumber daya utama, aktivitas kunci akan berhubungan dengan sumber daya utama dari perusahaan. Sumberdaya utama merupakan mesin, kandang dan bangunan yang menopang aktivitas utama yaitu aktivitas produksi. Aktivitas produksi ini terkait dengan transportasi dari kandang-Penerimaan telur-Penyeleksian telur- 
Fumigasi-Penyimpanan di cooling room-PengeramanTransfer-Candling-Pull chick. Menurut Lamarque (2005) perusahaan dapat terus berjalan dengan baik apabila memiliki aktivitas kunci yang berbeda dengan kompetitor atau aktivitas kuncinya sama dengan kompetitor namun dengan cara berbeda.

Alur proses produksi DOC dimulai dari kandang membawa telur hasil dari persilangan ayam kampung. Setelah menerima telur dilakukan penyeleksian telur di ruang seleksi telur untuk mendapatkan kualitas yang baik. Agar telur bersih dari kotoran dilakukan fumigasi yaitu pengasapan sebelum di simpan di ruang pendingin. Setelah di fumigasi disimpan di ruang pendinging dengan suhu $17^{\circ} \mathrm{C}$ kurang lebih selama 2 hari. Proses pengeraman dilakukan selama 18 hari menggunakan mesin pengeram.Setelah dierami dilakukan candling yaitu peneropangan dengan lampu pijar untuk melihat kondisi isi telur sebelum menetas. Proses pengeraman dilakukan selama 3 hari sampai menetas dan DOC yang terseleksi sesuai dengan standar perusahaan dikemas lalu siap dikirim ke konsumen.

Produksi DOC ayam kampung PT PQR pada tahun 2017 sebanyak 1,2 juta ekor/tahun. PT PQR ditunjuk sebagai supplier DOC ayam kampung untuk program pemerintah. Pada tahun 2018 PT PQR diminta untuk mengirimkan DOC ayam kampung sebanyak 4 juta ekor/tahun. PT PQR berencana agar permintaan pemerintah tersebut dapat dipenuhi dengan cara menambahkan jumlah produksi DOC ayam kampung. Perusahaan perlu memiliki program yang bertujuan untuk meningkatkan produksi ayam kampung dan pengembangan kapasitas dalam aspek produksi dan manajemen ayam kampung, kewirausahaan, pemasaran, penambahan nilai, penyimpanan catatan, dan penganggaran (Mapiye et al. 2008).

Perusahaan memiliki produk sampingan selain DOC ayam kampung. Produk sampingan merupakan hasil dari produk utama yang dimanfaatkan. Produk sampingan berupa ayam kampung hidup dan ayam kampung potong. Ayam kampung hidup berasal dari DOC ayam kampung yang tidak sesuai standar lalu dibesarkan di kandang sendiri dan dijual ke distributor penjualan ayam kampung hidup. Ayam kampung potong berasal dari ayam kampung hidup yang dibesarkan namun tidak sesuai dengan standar penjualan. Standar penjualan ayam kampung hidup biasanya dilihat dari bobot ayam kampung itu sendiri. Apabila tidak sesuai dengan standar bobot jual 0,5-1 kg/ekor, maka ayam kampung hidup dimasukkan ke rumah pemotongan ayam (RPA). Setelah dari RPA ayam kampung dikemas dan dijual ke pelanggan-pelanggan.

PT PQR berusaha untuk memasarkan produknya ke berbagai tuajuan dan segmen pasar. Namun saat ini untuk produk DOC ayam kampung dan ayam kampung hidup dijual kepada pemerintah. Pemasaran dilakukan oleh bagian pemasaran (marketing) di PT PQR. Sampai saat ini jumlah setiap tenaga pemasaran (Sales) produknya hanya berjumlah satu orang. Kegiatan pemasaran dilakukan oleh perusahaan dengan menggunakan media online dan mengikuti bazar UMKM di JABODETABEK. Bekerjasama dengan Balai Pengelola Alih Teknologi Pertanian (BPATP) untuk membantu memasarkan DOC ayam kampung ke peternak-peternak di Indonesia.

\section{Kemitraan Utama}

Elemen kemitraan dalam model bisnis dapat menggambarkan mitra mana saja yang mendukung bisnis PT PQR. Mitra usaha PT PQR antara lain BALITNAK (Balai Penelitian Ternak) Ciawi sebagai pemberi lisensi produk ayam kampung, PT. Medion Ardhika Bhakti sebagai pemasok vaksin, PT. Farmsco Feed Indonesia sebagai pemasok pakan DOC, PT Kemasan Indah Sejahtera sebagai pemasok kemasan dus DOC dan agen kargo sebagai pihak ketiga untuk membantu mendistribusikan DOC ayam kampung ke luar Pulau Jawa. Jenis hubungan kemitraan yang dijalin dengan pemasok apabila dilihat dari teori Osterwalder dan Pigneur (2015), maka masuk kedalam jenis hubungan pembeli dan pemasok yang dapat diandalkan. Jika dilihat dari motivasi dilakukannya hubungan kemitraan dengan pemasok adalah akuisisi sumber daya dan aktivitas tertentu. Hal ini karena perusahaan tidak membuat pakan dan vaksin DOC sendiri, melainkan menjalin hubungan kerjasama dengan pemasok untuk melengkapi kebutuhannya.

\section{Struktur Biaya}

Elemen struktur biaya menggambarkan biaya yang harus dikeluarkan untuk menjalankan sebuah bisnis. Pada elemen ini memfokuskan pada biaya yang paling penting untuk mengoperasikan bisnis. Terdapat dua jenis biaya yakni biaya tetap merupakan biaya yang dikeluarkan untuk pengadaan komponen pendukung 
proses produksi yang mana komponen tersebut dapat digunakan dalam beberapa kali proses produksi dan biaya variabel yang merupakan biaya yang habis digunakan dalam satu kali proses produksi (Pakage et al. 2018). Termasuk Biaya variabel yaitu biaya distribusi, operasional, vaksin, pakan dan royalti untuk BALITNAK. Termasuk biaya tetap yaitu indukan, gaji karyawan, mesin, dan bangunan. Biaya yang paling tinggi untuk memproduksi DOC ayam kampung berturut-turut adalah biaya pakan dan biaya vaksin. Harga pokok penjualan dipengaruhi oleh harga vaksin dan pakan yang berfluktuasi antar waktu. Variasi biaya vaksin juga dikarenakan penggunaan vaksin yang berbeda untuk setiap pelanggan tergantung preferensi pelanggan terhadap produk vaksin yang beredar di pasar.

\section{Implikasi Manajerial}

Langkah awal yang dilakukan adalah penambahan kapasitas produksi dengan cara menambahkan jumlah mesin pengeram dan penetas untuk memenuhi permintaan pelanggan. Penambahan kapasitas produksi digambarkan dalam perbaikan model bisnis yang sedang dijalankan saat ini. PT PQR dapat menambahkan jumlah karyawan marketing seiring bertambahnya jumlah produksi untuk membantu memasarkan produknya lebih banyak dengan memberi target penjualan kepada setiap karyawan. Selain itu melakukan kaderisasi untuk staf ahli pembibitan dan pembesaran dengan cara mengadakan pelatihan rutin oleh staf ahli pembibitan saat ini untuk mengantisipasi ketergantungan kepada keryawan tertentu. PT PQR dapat menjalin hubungan yang baik dengan pelanggan sebelumnya untuk menarik pelanggan yang lama maupun yang baru dengan cara melakukan pendampingan peternak dan melakukan kerjasama dengan perusahaan ayam kampung lainnya agar penjualan produk tidak menurun setelah usainya program pemerintah.

\section{KESIMPULAN DAN SARAN}

\section{Kesimpulan}

Hasil pemetaan model bisnis kanvas PT PQR memperlihatkan bahwa model bisnis yang dijalankan saat ini masih perlu ditingkatkan di beberapa elemen seperti customer relationship, key resources, key activities, dan key partnerships untuk dapat memenuhi permintaan pelanggan. Program perbaikan dapat berupa penambahan kapasitas produksi, penambahan jumlah karyawan, dan menjalin kerjasama dengan perusahaan ayam kampung lainnya yang lebih efisien dan efektif.

\section{Saran}

PT PQR dapat melakukan analisis kekuatan, kelemahan, peluang dan ancaman untuk memperbaiki bisnis model kanvas saat ini, serta menentukan rencana evaluasi terhadap model bisnis perbaikan. Bisnis model kanvas yang sudah diperbaiki dapat dijadikan alternatif strategi pengembangan perusahaan ke depannya. Perbaikan model bisnis kanvas berupa penambahan pada elemen key resources dengan ditambahkan mesin penetas dan mesin pengeram.

\section{DAFTAR PUSTAKA}

Abdelqader A, wollny C, Gauly M. 2007. Characterization of Local Chicken Production Systems and Their Potential Under Different Levels of Management Practice in Jordan. Tropical Animal Health and Production 39:155164.

Agustina TS. 2015. Kewirausahaa. Jakarta: Mitra Wacana Media.

Barnes NG, Jacobsen S. 2013. Adoption of Social Media by Fast-Growing Companies: Innovation Among the Inc. 500. Journal of Marketing Development andbell Competitiveness 7(1): 11-17. https:// doi.org/10.1007/s11250-007-9000-x.

Bell SJ, Auh S, Smalley K. 2005. Customer Relationship Dynamics: Service Quality and Customer Loyalty in the Context of Varying Levels of Customer Expertise and Switching Costs. Journal of the Academy of Marketing Science 33(2): 169-183. https://doi.org/10.1177/0092070304269111.

Brooks G, Heffner A, Henderson A. 2014. A SWOT Analysis of competitive knowledge from social media for a small start-up business. Review of Business Information Systems 18(1): 23-33. https://doi.org/10.19030/rbis.v18i1.8540.

Ching HY, Fauvel C. 2013. Criticisms, variations and experiences with business model canvas. European Journal of Agriculture and Forestry Research 1(2): 26-37.

Dewi NR. 2018. Formulasi strategi pengembangan bisnis salon XYZ [tesis]. Bogor: Institut Pertanian Bogor

Dudin M, Lyasnikov N, Leontva L, Reshetov A, 
Sidorenko V. 2015. Business model canvas as a basis for the competitive advantage of enterprise structures in the Industrial Agriculture. Journal Biosciences Biotechnology Research Asia 12(1): 887-894. https://doi.org/10.13005/bbra/1736.

Dirjen PKH. 2018. Statistik Peternakan dan Kesehatan Hewan. Jakarta: Direktorat Jenderal peternakan dan Kesehatan Hewan.

Hudang AK. 2016. Perencanaan pengembangan subsektor peternakan dalam upaya peningkatan perekonomian di Kabupaten Sumba Timur.Jurnal Riset Ekonomi dan Manajemen 16(2): 331-344. https://doi.org/10.17970/jrem.16.1602012.ID.

Kurniawan MFT, Darmawan DP, Nastiti NS. 2013. Strategi pengembangan agribisnis peternakan ayam petelur di Kabupaten Tabanan. Jurnal Manajemen Agribisnis 1(2): 53-66.

Lamarque E. 2005. Identifying key activities in banking firms: acompetence based analysis. Journal of Emerald Group Publishing Limited 10(7): 29-47. https://doi.org/10.1016/S07496826(04)07002-7.

Mapiye C,Mwale M,Mupangwal JF, Chimonyo M, Fotil R, Mutenje MJ. 2008. A research review of village chicken production constraints and opportunities in Zimbabwe. Asian-Aust. Journal of Animal Science 21(11):1680-1688. https:// doi.org/10.5713/ajas.2008.r.07.

Muryanto, Pramono D, Prasetyo T, Prawirodigdo S, Herwinarni EM, Kushartanti, Sugiyono, and Musawati I. 2009. Paket Teknologi Rekomendasi Ayam Potong Lokal (Ayam Hibrida). Ungaran: Balai Pengkajian Teknologi Pertanian (BPTP).

Nashwan SAB, Hassan H. 2017. Impact of customer relationship management (CRM) on customer satisfaction and loyalty: a systematic review.
Journal of Advanced Research in Business and Management Studies 6(1): 86-107.

Ostewalder A, Yves Pigneur. 2015. Business Model Generation. Jakarta: PT Elex Media Komputindo.

Pakage S, Hartono B, Fanani Z, Nugroho BA, Iyai DA. 2018. Analisis struktur biaya dan pendapatan usaha peternakan ayam pedaging dengan menggunakan closed house system dan open house system. Jurnal Peternakan Indonesia 20(3): 193-200. https://doi.org/10.25077/ jpi.20.3.193-200.2018.

Prabuwisudawan D,Rifin A, Djohar S. 2018. Strategi pengembangan balai inseminasi buatan lembang kabupaten bandung barat dengan pendekatan business model canvas. Jurnal Manajemen \& Agribisnis 4(3):317-327. https://doi. org/10.17358/jabm.4.3.317.

Sari TY, Hudoyo A, Nugraha A. 2015. Analisis finansial dan strategi pengembangan usaha perdagangan telur eceran: studi kasus di pasar tradisional Kota Bandar Lampung. Jurnal Ilmu-Ilmu Agribisnis 3(3): 243-250.

Shafer SM, Smith HJ, Linder JC. 2005. The power of business models. Business Horizons 48(3): 199-207. https://doi.org/10.1016/j. bushor.2004.10.014.

Zalkuwi J, Singh UP, Maurya A, Ibrahim A. 2015. Cost and return analysis of local chicken marketing in mubi north local government area of Adamawa State, Nigeria. International Journal of Environmental \& Agriculture Research 1:5-8.

Zott C, Amit R, Massa L. 2011. The business model: recent developments and future research. Journal of Management 37(4): 1019-1042. https://doi. org/10.1177/0149206311406265. 